\title{
CC16 levels correlate with cigarette smoke exposure in bronchial epithelial cells and with lung function decline in smokers
}

\author{
David Chi-Leung Lam ${ }^{*}$ D, Hoi-Hin Kwok', Wai-Cho Yu², Fanny Wai-San Ko ${ }^{3}$, Cheuk-Yin Tam", \\ Arthur Chun-Wing Lau ${ }^{5}$, Daniel Yee-Tak Fong ${ }^{6}$ and Mary Sau-Man Ip ${ }^{1}$
}

\begin{abstract}
Background: Club cell protein-16 (CC16) expression has been associated with smoking-related lung function decline. The study hypothesis was that CC16 expression in both serum and bronchial epithelium is associated with lung function decline in smokers, and exposure to cigarette smoke will lead to reduction in CC16 expression in bronchial epithelial cells.

Methods: In a cohort of community-based male Chinese subjects recruited for lung function test in 2000, we reassessed their lung function ten years later and measured serum levels of CC16. CC16 expression was further assayed in bronchial epithelium from endobronchial biopsies taken from an independent cohort of subjects undergoing autofluorescence bronchoscopy, and tested for correlation between CC16 immunostaining intensity and lung function. In an in-vitro model, bronchial epithelial cells were exposed to cigarette smoke extract (CSE), and the expression levels of CC16 were measured in bronchial epithelial cells before and after exposure to CSE.

Results: There was a significant association between $\mathrm{FEV}_{1}$ decline and serum $\mathrm{CC} 16$ levels in smokers. Expression of CC16 in bronchial epithelium showed significant correlation with FEV 1 /FVC. Bronchial epithelial cells showed significant decrease in CC16 expression after exposure to CSE, followed by a subsequent rise in CC16 expression upon removal of CSE.

Conclusions: Results of these clinical and laboratory investigations suggested that low serum CC16 was associated with smoking-related decline in lung function, demonstrated the first time in a Chinese cohort. The data also lend support to the putative role of CC16 in protection against smoking-related bronchial epithelial damage.

(Abstract word count: 243)
\end{abstract}

US clinical trial registry: NCT01185652, first posted 20 August, 2010.

Keywords: Biomarkers, Lung function, Smoking, Spirometry, Forced expiratory volume

\section{Background}

Tobacco smoking accelerates lung function decline in adults $[1,2]$ and is the major cause of chronic obstructive pulmonary disease (COPD), although not all smokers will develop COPD. COPD is characterized by airflow obstruction, defined by a reduced ratio of forced expiratory volume in one second to forced vital capacity $\left(\mathrm{FEV}_{1} / \mathrm{FVC}\right)$ on spirometry [3]. Some serum biomarkers

\footnotetext{
* Correspondence: dcllam@hku.hk

${ }^{1}$ Department of Medicine, Li Ka Shing Faculty of Medicine, University of Hong Kong, 21 Sassoon Road, Pokfulam, HK, China

Full list of author information is available at the end of the article
}

like interleukin-6 (IL-6), interleukin-8 (IL-8) and monocyte chemoattractant protein-1 (MCP-1) have been found to be associated with airway inflammation in obstructive lung diseases, including COPD [4], asthma and bronchiectasis $[5,6]$.

Club cell protein-16 (CC16) is a pneumoprotein that is secreted by club cells in the distal airways [7]. Low serum levels of CC16 have been associated with decline in $\mathrm{FEV}_{1}$ in patients with COPD in three cohorts [8] and this relationship has also been shown in young smokers who developed COPD later in their lifespan [8]. The serum levels of $\mathrm{CC} 16$ were reported to be lower in 
smokers compared to non-smokers [9]. CC16 is regarded as a marker of peripheral lung injury [10] and its expression is associated with anti-inflammatory action [11]. Exposure to cigarette smoke has been shown to be associated with reduction in the numbers of club cells in bronchial epithelium and serum CC16 concentrations in animal model [12]. Low levels of serum CC16 were associated with decline in $\mathrm{FEV}_{1}$ in COPD subjects (ECLIPSE and Lung Health study) [13-16]. Although no significant correlations could be found between serum CC16 levels and COPD severity stratified by $\mathrm{FEV}_{1}$ values [15], CC16 expression in the airway was inversely correlated with the severity of airflow limitation in COPD [17]. Experiments with CC16 knockout mouse model suggested that $\mathrm{CC} 16$ has anti-inflammatory action and low CC16 expression in murine airway was associated with increased airway inflammation and alveolar loss [12]. Further clinical studies in human subjects will confirm the roles of CC16 in smoking-related lung function decline.

We hypothesized that CC16 expression in the airways and in circulation would be reduced with smoking, resulting in decline in lung function predisposing to airflow obstruction. We addressed this hypothesis through studies conducted on two independent clinical samples, and an in-vitro model of cigarette smoke exposure.

\section{Methods}

\section{Subject populations}

A community cohort of male smokers for follow-up of lung function

A community cohort of Chinese subjects had been recruited in year 2000 by random digital dialing for lung function assessment which was done in eight hospitals in Hong Kong, and the data of non-smokers have been used for formulation of local reference values for lung function tests $[18,19]$. All the men recruited in year 2000 were contacted and invited to return for this study in 2010. Only men were recruited because we had a small number of female smokers in the recruited sample 10 years ago, and we would not be able to meet the statistical power and sample size requirement for this study if female subjects were included. Lung function (spirometry) assessment and blood for assay of serum biomarker levels were done in this return visit. The study was approved by Institutional Review Board of the University of Hong Kong/Hong Kong Hospital Authority Hong Kong West Cluster (HKHA HKWC 08-428) and the research was carried out in accordance with the Declaration of Helsinki (2008). Informed written consents were obtained, lung function tests were repeated and a $10 \mathrm{ml}$ venous blood sample was obtained from consented subjects. Lung function tests were performed in the lung function laboratories of three hospitals
(Queen Mary Hospital, Prince of Wales Hospital and the Princess Margaret Hospitals, Hong Kong) with the Vmax Encore lung function test system (CareFusion, San Diego, CA, USA) according to the American Thoracic Society - European Respiratory Society recommendations [20]. Changes in $\mathrm{FEV}_{1}$ and $\mathrm{FVC}$ were defined as the difference in the respective values between the latest measurements in 2010 and the corresponding values in 2000, i.e. lung function decline: $\Delta \mathrm{FEV}_{1}(\mathrm{~L})=\mathrm{FEV}_{1(2010)}-$ $\mathrm{FEV}_{1(2000)}$ and $\triangle \mathrm{FVC}(\mathrm{L})=\mathrm{FVC}_{(2010)}-\mathrm{FVC}_{(2000)}$. The annual decline of lung function parameters were calculated with respect to the number of months between the two assessments in years 2000 and 2010 respectively.

\section{An independent sample of subjects for correlation of CC16 expression in endoscopic bronchial biopsy with spirometry parameters}

An independent sample cohort who presented with sputum cytological atypia was recruited consecutively. The study was approved by Institutional Review Board of the University of Hong Kong/Hong Kong Hospital Authority Hong Kong West Cluster (HK HA HKWC 09-120). All subjects had recent chest imaging which did not show any lesion accountable for the sputum detection of atypical cells. They received lung function tests followed by bronchoscopy with autofluorescence imaging and endobronchial biopsy.

Chronic smokers were asked to stop smoking at least on the day of lung function tests and bronchoscopy. After diagnostic specimens were taken from autofluorescence magenta areas, additional bronchial biopsies were taken from the adjacent green fluorescent areas (green fluorescent areas represent normal autofluorescence from bronchial epithelium).

\section{Definition of smokers}

Non-smokers were subjects who have never smoked in their life-time. Smokers included current smokers and ex-smokers who have been smoking for more than twelve months in the past but have quitted smoking for at least twelve months before recruitment.

\section{Immortalized human bronchial epithelial cell lines}

The origins and characteristics of human bronchial epithelial cell lines were described in supplement. Four immortalized bronchial epithelial cell lines, HBEC-KT 2-5, were used (from John Minna MD, University of Texas Southwestern Medical Center at Dallas, Texas, USA) [21]. Another four bronchial epithelial cell lines were established from endobronchial biopsy of local healthy Chinese subjects [22] with the same methods [21] and these new cell lines were named HKBS62N-KT, HKBS65.2 N-KT, HKBS150N-KT, HKBS160N-KT [22]. All these human bronchial epithelial cell lines were 
derived from smokers, except HKBS150N-KT which belonged to a non-smoker.

\section{Enzyme-linked immunosorbent assay (ELISA) for serum biomarker assay}

Serum biomarkers were assayed with and ELISA for serum CC16 levels (RD19102220, BioVendor R\&D, Asheville, NC, USA). The procedures were all performed according to manufacturers' protocols.

\section{CC16 immunohistochemistry}

Formalin-fixed paraffin-embedded (FFPE) tissue $(4 \mu \mathrm{m}$ section) of endobronchial biopsies were de-paraffinized and heat-mediated antigen retrieval ( $\left.95{ }^{\circ} \mathrm{C} 30 \mathrm{mins}\right)$ was performed with Tris buffer (10 mM Tris, $1 \mathrm{mM}$ EDTA, $\mathrm{pH}=9$ ). The endogenous peroxidase activity of the tissue was removed by treatment with hydrogen peroxide $(3 \%, v / v)$. The sections were blocked with protein block reagent (Dako, Carpinteria, CA, USA) for $30 \mathrm{~min}$ and then incubated with primary mouse-anti-human CC16 antibody (E11, 1:10000, Santa Cruz Biotechnology, Santa Cruz, CA, USA) or negative control mouse IgG1 (1:10000, Dako) at $4{ }^{\circ} \mathrm{C}$ overnight. The specimens were then further incubated with rabbit-anti-mouse secondary antibody (1:400, Dako) at $37^{\circ} \mathrm{C}$ for $30 \mathrm{~min}$. Signal amplification was performed with HRP EnVision+ System (Dako), and the coloured product was developed using DAB substrate chromogen system (Dako) for $3 \mathrm{~min}$. The sections were counter-stained with Hematoxylin. The immunohistochemical staining intensity (Grade 0-3) of CC16 expression in bronchial epithelial cells was scored by two independent investigators (DCL and HHK) who were initially blind to the smoking history of the samples. The immunostaining intensity levels of $\mathrm{CC} 16$ in bronchial epithelium were scored as 0 (negligible), 1 (weak), 2 (strong intensity) compared with negative serum control. These scores were used for correlation with lung function parameters.

\section{Cell culture and cigarette smoke treatment}

All the eight cell lines were cultured in triplicates in Keratinocyte-serum-free medium (KSFM) supplemented with bovine pituitary extract $(50 \mu \mathrm{g} / \mathrm{ml})$, human recombinant epidermal growth factor (5 ng/ $\mathrm{ml}$ ) (Life Technology, Grand Island, NY, USA) and penicillin and streptomycin $(1 \%, v / \mathrm{v})$ (Life Technology, Grand Island, NY, USA). Cells were kept at $37{ }^{\circ} \mathrm{C}$ in $5 \% \quad \mathrm{CO}_{2}$ incubator. Cells $\left(2 \times 10^{5}\right.$ cells/well $)$ were seeded onto $60 \mathrm{~mm}$ dish overnight and were starved in supplement-free medium for another overnight. The same eight cell lines cultured without CSE addition were cultured in triplicates and they were used as controls.
Cigarette smoke extract (CSE) was prepared as described elsewhere [23]. Briefly, aqueous phase CSE was prepared by bubbling two filter-removed commercial cigarettes (12 mg Tar, $1.0 \mathrm{mg}$ nicotine; Marlboro, Philip Morris, Inc., Richmond, VA, USA) into $20 \mathrm{ml}$ PBS. The extract was then filtered through a $0.22 \mu \mathrm{m}$ syringe filter. The absorbance of the extract at $320 \mathrm{~nm}$ was measured and the stock solution was referred as 100\% CSE. Cell viability was monitored with Trypan Blue in MTT assays.

\section{Ribonucleic acid (RNA) extraction and real-time quantitative} polymerase chain reaction (PCR) analysis

At time 0, 96 and $192 \mathrm{~h}$, total RNA was extracted by TRIzol reagent according to manufacturer's protocol. RNA was then reversely transcribed into complementary DNA (cDNA) by the QuantiNova Reverse Transcription Kit (Qiagen, Hilden, Germany). The relative expression of target mRNA for CC16 [24] was quantified by real-time quantitative PCR with QuantiFast SYBR Green Kit (Qiagen) on a StepOnePlus real-time PCR system (Applied Biosystem, Foster City, CA, USA). The primer sequences were listed in Table 1. The relative expression of the target gene was normalized by the level of glyceraldehyde-3phosphate dehydrogenase (GAPDH) [25] as the reference gene and then calculated by $\Delta \Delta \mathrm{C}_{\mathrm{t}}$ method.

\section{Statistical analysis}

Subject demographics were summarized with descriptive statistics. The differences between smokers and nonsmokers were examined by student $t$ test, $X^{2}$ test or Fisher's exact test where appropriate, using IBM SPSS software version 21. Mean and standard deviation (SD) or standard errors (SE) were used for continuous variables in normal distribution. Pearson correlations were applied to tests for the correlations between clinical parameters of age, smoking status and lung function decline. Partial correlations were applied for correlations of immunohistochemical staining scores with lung function parameters, adjusted for age, gender and smoking status. Multiple linear regression models were built to determine the clinical parameters of age, height, smoking habits, $\mathrm{FEV}_{1}$ values and log serum biomarker levels that could independently predict lung function decline. All $p$ values were two-sided and $p<0.05$ was considered statistically significant. For the in vitro experiments, one-way analysis of variance (ANOVA) followed by Tukey's multiple comparison tests were performed across multiple groups.

\section{Results}

Patient characteristics

All of the 1085 male consecutive subjects who had lung function tests done in $2000[18,19]$ were contacted again in 2010 (Fig.1). 683 subjects either declined to 
Table 1 Demographics of the 397 male subjects recruited for this study

\begin{tabular}{|c|c|c|c|c|}
\hline & Total & Non-smoker & Ever smoker & $P$ value \\
\hline Number (\%) & 397 & $168 \quad(42.3)$ & $229 \quad(57.7)$ & \\
\hline \multicolumn{4}{|c|}{ Age, years (mean $\pm S E$ ) } & NS \\
\hline 2000 & $47.7 \pm 12.5$ & $46.6 \pm 12.3$ & $48.5 \pm 12.7$ & \\
\hline 2010 & $56.5 \pm 12.6$ & $55.4 \pm 12.3$ & $57.2 \pm 12.8$ & \\
\hline \multicolumn{4}{|l|}{ BMI } & NS \\
\hline 2000 & $24.69 \pm 3.26$ & $24.98 \pm 3.38$ & $24.48 \pm 3.16$ & \\
\hline 2010 & $24.69 \pm 3.33$ & $24.93 \pm 3.38$ & $24.47 \pm 3.28$ & \\
\hline
\end{tabular}

Smoking amount, Pack-year (mean \pm SE)

$\begin{array}{ll}2000 & 17.1 \pm 10.9 \\ 2010 & 24.7 \pm 20.3\end{array}$

Presence of AFL

$\begin{array}{rrr}2000 & 21(5.3) & 2 \\ 2010 & 65(17.2) & 20\end{array}$

Development of AFL

$\begin{array}{llrr}\text { New AFL } & 44(11.1) & 18 & 26 \\ \text { Stay AFL } & 21(5.2) & 2 & 19 \\ \text { No AFL } & 332(83.6) & 158 & 174\end{array}$

Lung function parameters 2000

$\begin{array}{cccc}\begin{array}{c}\text { FEV1 in liter } \\ \text { Mean FEV } 1\end{array} & 3.01 \pm 0.65 & 3.11 \pm 0.64 & 2.94 \pm 0.65 \\ \begin{array}{c}\text { (\% pred) } \\ \text { FVC in liter }\end{array} & 3.80 \pm 0.71 & 3.84 \pm 0.72 & 3.76 \pm 0.69 \\ \begin{array}{c}\text { Mean FVC } \\ \text { (\% pred) }\end{array} & 105.9 \pm 4.7 & 106.9 \pm 2.3 & 105.2 \pm 5.5 \\ \text { FEV1/FVC (\%) } & 79.2 \pm 6.9 & 80.9 \pm 5.2 & 77.8 \pm 7.7 \\ \quad \begin{array}{l}\text { Lung function parameters } 2010 \\ \text { FEV1 in liter }\end{array} & 2.81 \pm 0.66 & 2.85 \pm 0.61 & 2.79 \pm 0.69 \\ \begin{array}{c}\text { Mean FEV1 } \\ \text { (\% pred) }\end{array} & 100.0 \pm 4.3 & 102.3 \pm 1.1 & 98.3 \pm 7.1 \\ \text { FVC in liter } & 3.73 \pm 0.75 & 3.74 \pm 0.74 & 3.73 \pm 0.77 \\ \begin{array}{c}\text { Mean FVC } \\ \text { (\% pred) }\end{array} & 104.7 \pm 2.3 & 105.4 \pm 4.5 & 104.1 \pm 6.1 \\ \text { FEV1/FVC (\%) } & 75.2 \pm 7.7 & 76.2 \pm 6.6 & 74.4 \pm 8.3\end{array}$

Serum Biomarker (in 2010)

$\begin{array}{lllll}\log \text { CC16 } & 0.72 \pm 0.22 & 0.74 \pm 0.22 & 0.69 \pm 0.23 & 0.029^{*}\end{array}$

$\mathrm{BMI}=$ body mass index; $\mathrm{NS}=$ not significant; $\mathrm{AFL}=$ airflow limitation; $\mathrm{FEV}_{1}=$ forced expiratory volume in one second; FVC = forced vital capacity. ${ }^{*} p<0.05$ for comparison between smokers and non-smokers

return for study participation or could not be contacted after six separate attempts (phone calls) at least one week apart at different times. 402 subjects returned after successful phone calls but five of them declined participation upon return, thus 397 subjects completed assessment (Fig. 1). The mean age was $56.5 \pm 12.6$ years (Table 1 ). There were 168 non-smokers (42.3\%), while 229 (57.7\%) were ever-smokers (including 21 subjects who have quitted while the other 208 subjects remained as regular smokers in the last ten years or so). Among ever-smokers, the mean amount of smoking was $24.7 \pm 20.3$ pack-years. The demographic characteristics of these subjects are summarized in Table 1. These recruited subjects have no significant respiratory symptoms at the time of assessment. Airflow limitation (AFL) (defined as $\mathrm{FEV}_{1} / \mathrm{FVC}<$ $70 \%$ on spirometry) [3] was found in $65(17.2 \%)$ of subjects with mean $\mathrm{FEV}_{1} / \mathrm{FVC}$ of $67.5 \pm 2.5 \%$, most of which were considered as mild degree of airflow obstruction with mean $\mathrm{FEV}_{1}$ (\% of predicted) at $98.3 \%$ (Table 1).

\section{Serum levels of $\mathrm{CC} 16$ correlated with lung function decline}

Serum CC16 levels showed significant correlation with $\mathrm{FEV}_{1}$ decline, adjusted for age and smoking amount. The serum level of $\mathrm{CC} 16$ was found to correlate with spirometric parameters of $\mathrm{FEV}_{1}\left(r=-0.23, p=0.014^{*}\right)$, but not FVC $(r=-0.108, p=0.054)$ or $\mathrm{FEV}_{1} / \mathrm{FVC}(r=0.212, p=0.158)$.

When the analyses were separated for smokers and non-smokers, serum CC16 levels showed a significant correlation with $\mathrm{FEV}_{1}\left(r=-0.124, p=0.027^{*}\right)$ in smokers but not in non-smokers. A significant regression model was found with regression coefficient of $0.091, p=0.014^{*}$ suggesting that with every $1 \mathrm{ng} / \mathrm{ml}$ decrease in serum CC16 level there could be an additional $56 \mathrm{ml}$ of drop in $\mathrm{FEV}_{1}$ over the past $10-15$ years, i.e. an average of drop of 3.7-5.6 ml/year in addition to the expected smokingrelated decline in $\mathrm{FEV}_{1}$ (Table 2).

\section{CC16 expression in human bronchial epithelium correlated with lung function}

Endobronchial biopsies of 34 subjects were evaluated with CC16 immunostaining. The demographic characteristics of these subjects, including smoking status and lung function parameters, are summarized in Table 3. CC16 expression levels (Fig. 2) in their bronchial epithelium showed significant correlation with $\mathrm{FEV}_{1} / \mathrm{FVC}\left(r=-0.689, p<0.001^{* * * *}\right)$, adjusted for age, gender and smoking amount. No significant correlation was found between $\mathrm{CC} 16$ expression and lung function parameters of $\mathrm{FEV}_{1}$ and $\mathrm{FVC}$.

CSE exposure for immortalized bronchial epithelial cells All the normal bronchial epithelial lines demonstrated consistent initial significant decrease in both CC16 mRNA $(p<0.001)$ and CC16 protein expression $(p<0.001)$ with CSE exposure for $96 \mathrm{~h}$, followed by a non-significant rise in both CC16 mRNA and protein expression levels with removal of CSE $(p>0.05)$ (Fig. 3).

Cell viability is not affected when the CSE concentration is below $10 \%$ (Fig. 4). 


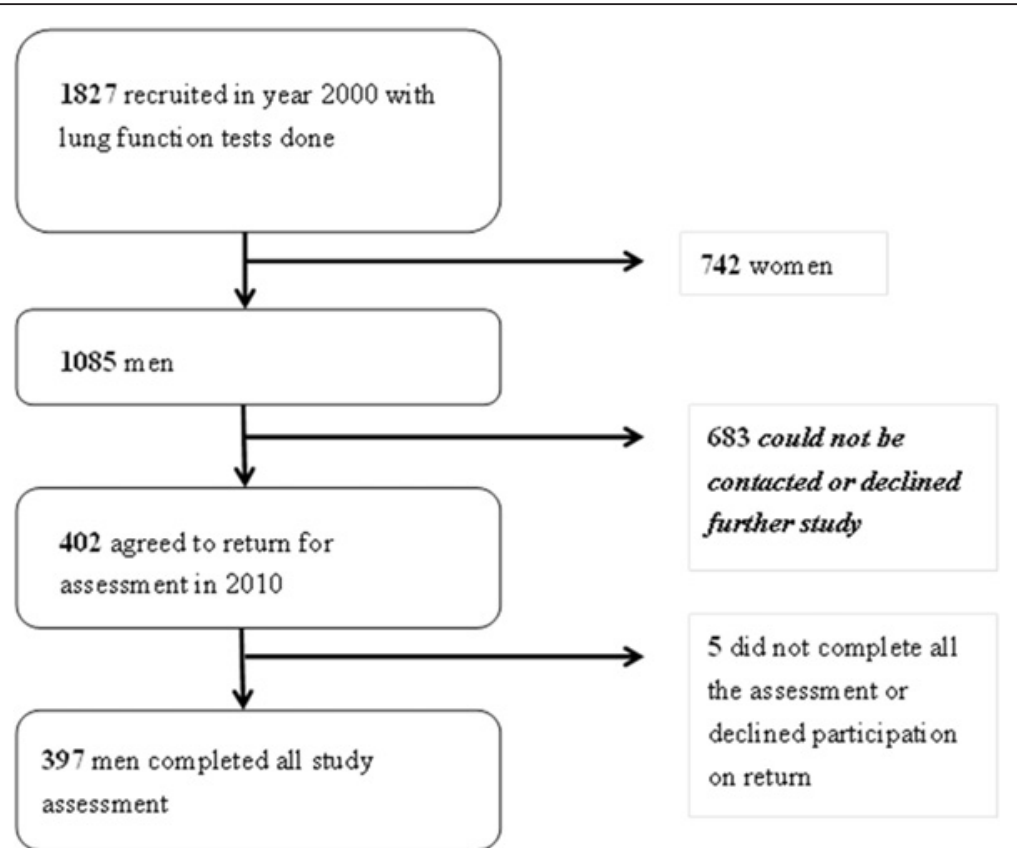

Fig. 1 A study flow chart to show the recruitment of subjects

\section{Discussion}

In this study we have demonstrated a significant association between $\mathrm{CC} 16$ expression and decline in $\mathrm{FEV}_{1}$ in smokers but not in non-smokers. In an independent sample of subjects with endobronchial biopsy, there was a significant correlation between CC16 expression in bronchial epithelium and $\mathrm{FEV}_{1} / \mathrm{FVC}$, i.e. the lower the $\mathrm{CC} 16$ expression the lower was the $\mathrm{FEV}_{1} / \mathrm{FVC}$ ratio. This is also the first demonstration of a consistent reduction in both CC16 mRNA and protein expression in immortalized bronchial epithelial cell lines after being exposed to CSE, followed by a subsequent rise of CC16 expression with CSE removal.

The recent report from Guerra et al. demonstrated the relationship between low serum $\mathrm{CC} 16$ at baseline and greater lung function decline over the subsequent 814 years in three epidemiological cohorts of adults (the population-based Tuscon Epidemiological Study of Airway Obstructive Disease [TESAOD], the European Community Respiratory Health Survey [ECRHS] and the Swiss Cohort Study on Air Pollution and Lung Diseases in Adults [SAPALDIA]) [8]. In that analysis, the three

Table 2 Multiple linear regression modeling demonstrated significant prediction of $\mathrm{FEV}_{1}$ decline with log serum CC16 levels

\begin{tabular}{llll}
\hline & Coefficient & SE & $P$ values \\
\hline Age, years & 0.018 & 0.003 & $<0.001^{*}$ \\
Smoking amount, pack- years & 0.099 & 0.065 & 0.126 \\
Log serum CC16 levels & -0.091 & 0.147 & $0.014^{*}$ \\
\hline
\end{tabular}

databases designed for different studies were used although the different cohorts shared similar baseline characteristics [8]. Meta-analysis of the data from the three cohorts showed that with decline of $\mathrm{CC} 16$ by one standard deviation, there was an associated decline of $\mathrm{FEV}_{1}$ by $4.4 \mathrm{ml} /$ year [8]. Baseline CC16 levels were found to be lower in smokers who developed COPD, compared to those smokers who were not found to have COPD later in life, and thus CC16 was suggested to be related to the risk of development of COPD [8]. Our findings that low serum CC16 correlated with greater lung function decline among smokers over the past ten

Table 3 Demographics of the 34 subjects recruited with endobronchial biopsy for CC16 immunostaining performed

\begin{tabular}{llll}
\hline & $\begin{array}{l}\text { Non-smokers } \\
(n=10)\end{array}$ & $\begin{array}{l}\text { Ex-smokers } \\
(n=11)\end{array}$ & $\begin{array}{l}\text { Chronic smokers } \\
(n=13)\end{array}$ \\
\hline Men $^{*}$ & $3(30 \%)$ & $11(100 \%)$ & $13(100 \%)$ \\
Age (years) & $56.3 \pm 14.7$ & $63 \pm 9.5$ & $67.4 \pm 7.1$ \\
FEV $_{1}$ & $2.2 \pm 0.6 \mathrm{~L}$, & $2.4 \pm 0.5 \mathrm{~L}$, & $2.1 \pm 0.3 \mathrm{~L}$, \\
(Liters, \% pred) & $102.3 \pm 2.8 \%$ & $97.5 \pm 6.5 \%$ & $89.1 \pm 5.2 \%$ \\
FVC & $2.9 \pm 0.6 \mathrm{~L}$, & $3.6 \pm 0.5 \mathrm{~L}$, & $3.4 \pm 0.5 \mathrm{~L}$, \\
(Liters, \% pred) & $113.4 \pm 4.6 \%$ & $106.0 \pm 5.3 \%$ & $92.3 \pm 7.2 \%$ \\
FEV 1 /FVC (\%) & $73.6 \pm 11.8$ & $66.6 \pm 12.5$ & $62.9 \pm 10.8$ \\
CC16 intensity & & & \\
\multicolumn{1}{c}{0} & $2(20 \%)$ & $3(27 \%)$ & $5(39 \%)$ \\
\multicolumn{1}{c}{1} & $3(30 \%)$ & $4(36 \%)$ & $3(23 \%)$ \\
2 & $5(50 \%)$ & $4(36 \%)$ & $5(39 \%)$ \\
\hline
\end{tabular}

Significance testing used analysis of variance for continuous variables and chi-square for categorical variables. ${ }^{*} p<0.001$. $\mathrm{FEV}_{1}=$ forced expiratory volume in $1 \mathrm{~s}$. $\mathrm{FVC}=$ forced vital capacity. $\mathrm{CC} 16=$ Club cell protein-16 


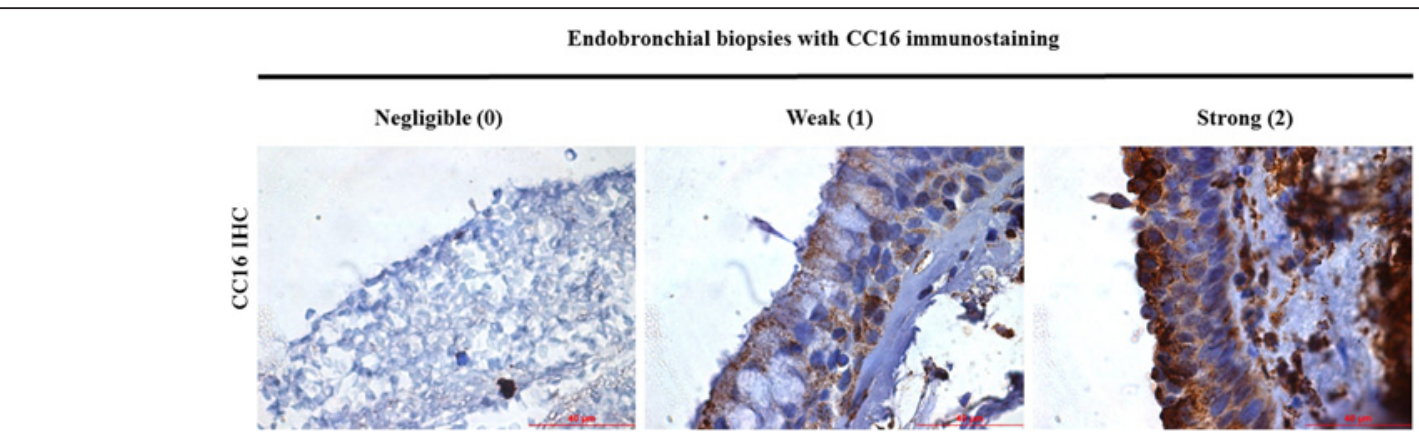

Fig. 2 Immunostaining for CC16 expression in endobronchial biopsies showing (A) Negligible staining (scored as 0 with the same intensity in bronchial epithelium) in control and (B) Weak staining (scored as 1) and (C) Strong staining (scored as 2) of CC16 in the bronchial epithelium. Note: Immunostaining were scored with the bronchial epithelial cytoplasmic staining intensity, not the stromal or nuclear staining intensity

years complement that of previous cohorts. This is the first time such correlation is demonstrated in Chinese. However, such correlation was not evident in nonsmokers in our Chinese cohort, while a low CC16 in association with lung function loss in both smokers and non-smokers was reported for Caucasian cohorts [8]. Serum CC16 level reduction could be a more sensitive biomarker for early detection of lung function decline in smokers than in non-smokers. We have only performed one repeat lung function test with a corresponding serum biomarker assessment, and hence we are not able to delineate the pattern of lung function decline over the ten years. Furthermore, we have included only male smokers in our analysis. Given the low female smoking prevalence at $5.6 \%$ in the local population, we had a small number of female smokers in the recruited sample 10 years ago, and we would not be able to meet the statistical power and sample size requirement for this study if female subjects were included.

There were previous reports of increase in CC16 mRNA expression in human bronchial epithelial cell lines after exposure to interferon- $\gamma$ [26], tumor necrosis factor- $\alpha$ [27] and interleukin-10 [28]. These were believed to represent the roles of CC16 in mediating inflammation in airway epithelial cells. This is the first time a direct effect of CSE on bronchial epithelial cells is demonstrated, with reduction in CC16 mRNA expression. The subsequent rise of CC16 mRNA expression in the bronchial epithelial cells upon CSE removal may imply that smoking cessation may well restore the protective role of CC16 against lung function loss.

This study has several unique findings: this is the first report of longitudinal cohort on CC16 and lung function decline in Chinese; the first demonstration

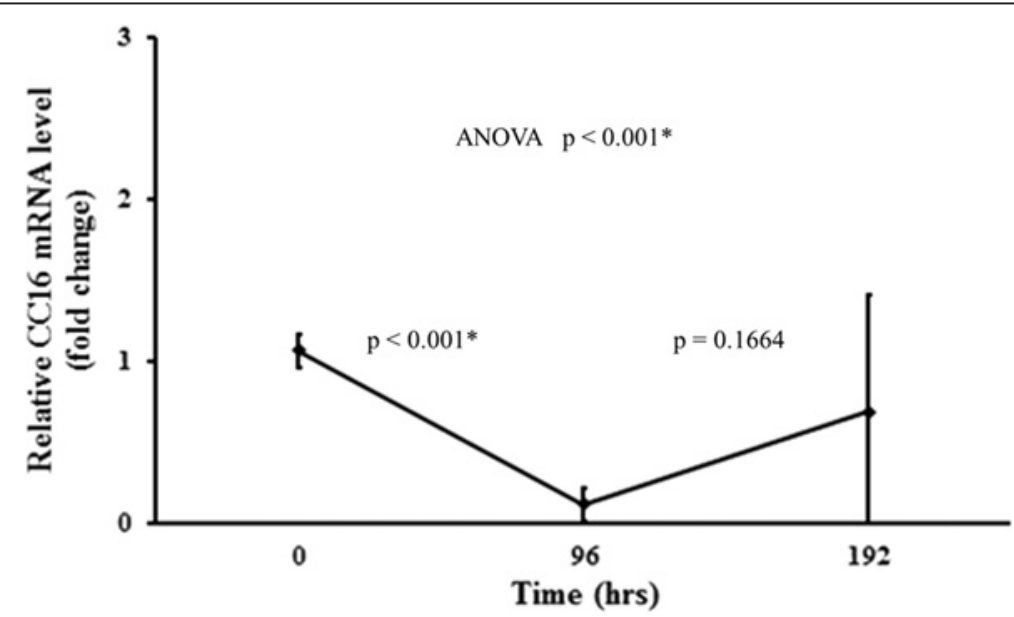

Fig. 3 Effects of cigarette smoke extract (CSE) exposure on the expression levels of CC16 mRNA. Eight immortalized normal human bronchial epithelial cell lines were treated with CSE for $96 \mathrm{~h}$ after overnight serum starvation. CSE was then removed and washed with PBS for further culture for another $96 \mathrm{~h}$ in the absence of CSE. Data were shown as mean $+/-$ standard deviation of eight cell lines and were analyzed by one-way ANOVA followed by Tukey's multiple comparison tests. The $p$ values for comparison of group means at 0 h vs 96 h, and 96 h vs 192 h, are also listed. ${ }^{*} p<0.001$ vs PBS vehicle control 
HKBS62N-KT

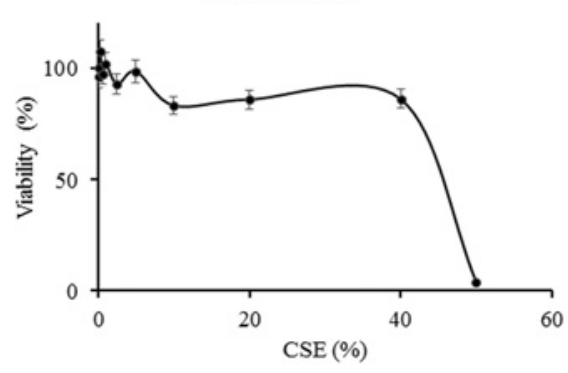

HKBS65.2N-KT

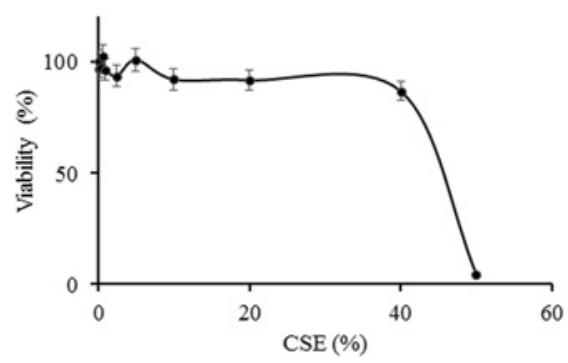

HKBS150N-KT

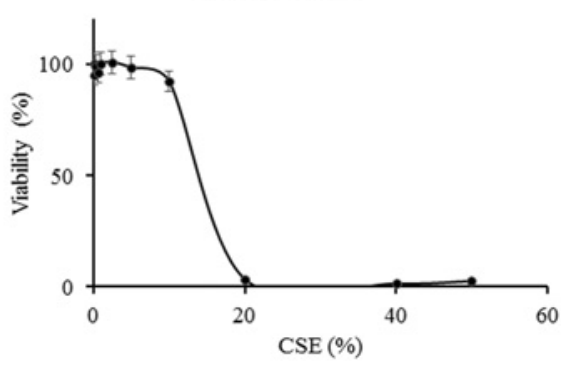

HKBS160N-KT

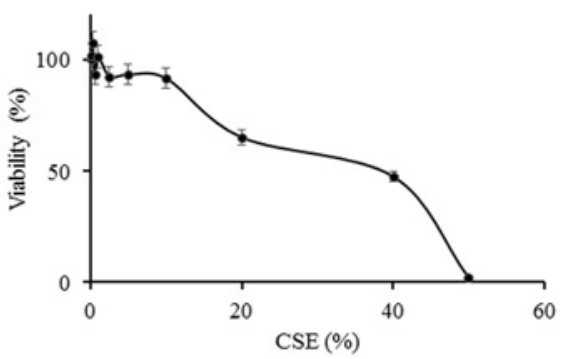

Fig. 4 Cell viability monitoring with Trypan Blue and MTT assays for different cell lines during experiments

of the correlation of CC16 expression in bronchial epithelium and lung function parameter indicative of airflow obstruction; and the first in vitro demonstration of the suppression of CC16 in normal bronchial epithelial cells after cigarette smoke exposure. Although a causal relationship between lower CC16 and worse lung function could not be ascertained from their association as found in the clinical studies, the in vitro study demonstrated that CSE stimulation led to a transient but significant drop in CC16 mRNA expression in bronchial epithelial cells. Further studies into the detailed molecular mechanisms leading to downstream effects of smoking-related transcriptional control of CC16 expression and lung function decline are warranted.

\section{Conclusions}

We demonstrated that serum CC16 levels were associated with lung function decline in this Chinese cohort. The level of CC16 expression in endoscopic biopsies of bronchial epithelium was also found to be correlated with $\mathrm{FEV}_{1} / \mathrm{FVC}$ ratio. To our knowledge, this is the first time that CC16 expression in human bronchial epithelium is shown to correlate with $\mathrm{FEV}_{1}$ / FVC ratio, a lung function parameter which represents airflow limitation. CSE resulted in significant reduction of CC16 expression in bronchial epithelial cells, with subsequent rise of CC16 expression upon cessation of CSE. This gives further support to the role of CC16 in smoking-related lung function decline and predisposition to chronic airways obstruction, and may imply that CC16 could be a potential target for anti-inflammation in smokers. Further mechanistic studies are warranted to understand the roles of CC16 in translating to smoking-related lung function changes.

\section{Abbreviations}

AFL: Airflow limitation; CC16: Club cell protein-16; COPD: Chronic obstructive pulmonary disease; CSE: Cigarette-smoke extract; ELISA: Enzyme-linked immunosorbent assay; $\mathrm{FEV}_{1}$ : Forced expiratory volume in 1 second; FFPE: Formalin-fixed paraffin-embedded; FVC: Forced vital capacity; IL: Interleukin; MCP-1: Monocyte chemoattractant protein-1; mRNA: Messenger ribonucleic acid; PCR: Polymerase chain reaction; RNA: Ribonucleic acid

\section{Acknowledgements}

The authors would like to acknowledge the technical assistance by Mr. Kenneth MK Lau, Ms. Vanessa Lai and Ms. Amy Cheung, and the statistical support provided by Ms. Crystal Kwan and Ms. Peony Chong.

\section{Funding}

The research work described in this manuscript was supported in part by the Hong Kong Lung Foundation Research Grant for the lung function study and serum biomarker tests with approved grant entitled 'A study on Smoking-related Lung function abnormalities and correlation with serum biomarkers in Chinese' and the University of Hong Kong YC Chan Scientist Award with a research grant that supported the testing of serum biomarkers in this project in relation to airway and lung function.

\section{Availability of data and materials}

The datasets used and/or analyzed is available from the corresponding author on reasonable request.

\section{Authors' contributions}

All authors contributed to and approved the final draft of the manuscript. All authors have read and approved the final manuscript. Conception and 
design: DCL, HHK, MSI Clinical data collection: DCL, WCY, FWK, CYT, ACL, MSI Laboratory experiments: DCL, HHK Data analysis: DCL, HHK, DYF, MSI. Manuscript drafting DCL, MSI.

\section{Ethics approval and consent to participate}

The study was approved by Institutional Review Board of the University of Hong Kong/Hong Kong Hospital Authority Hong Kong West Cluster (HKHA HKWC 08-428 and 09-120) and the research was carried out in accordance with the Declaration of Helsinki (2008). Informed written consents were obtained from all participating subjects.

\section{Consent for publication}

Not applicable.

\section{Competing interests}

The authors declare that they have no competing interest.

\section{Publisher's Note}

Springer Nature remains neutral with regard to jurisdictional claims in published maps and institutional affiliations.

\section{Author details}

'Department of Medicine, Li Ka Shing Faculty of Medicine, University of Hong Kong, 21 Sassoon Road, Pokfulam, HK, China. 'Department of Medicine and Geriatrics, Princess Margaret Hospital, Lai King, HK, China. ${ }^{3}$ Department of Medicine and Therapeutics, the Chinese University of Hong Kong, Shatin, HK, China. ${ }^{4}$ Department of Medicine and Geriatrics, Tuen Mun Hospital, 23, Tsing Chung Koon Rd, Tuen Mun, HK, China. ${ }^{5}$ Department of Intensive Care, Pamela Youde Nethersole Hospital, 3, Lok Man Rd, Chai Wan, HK, China. ${ }^{6}$ School of Nursing, Li Ka Shing Faculty of Medicine, University of Hong Kong, 21 Sassoon Road, Pokfulam, HK, China.

Received: 21 September 2017 Accepted: 1 March 2018 Published online: 16 March 2018

\section{References}

1. Fletcher C, Peto R. The natural history of chronic airflow obstruction. Br Med J. 1977;1(6077):1645-8.

2. Drummond MB, Hansel NN, Connett JE, Scanlon PD, Tashkin DP, Wise RA. Spirometric predictors of lung function decline and mortality in early chronic obstructive pulmonary disease. Am J Respir Crit Care Med. 2012; 185(12):1301-6.

3. Global Strategy for the Diagnosis, Management and prevention of COPD, global initiative for chronic obstructive lung disease (GOLD) 2016.2016 Available from: http://wwwgoldcopdorg/

4. Dickens JA, Lomas DA. CC-16 as a biomarker in chronic obstructive pulmonary disease. COPD. 2012;9(5):574-5.

5. Celli BR, Locantore N, Yates J, Tal-Singer R, Miller BE, Bakke P, Calverley P, Coxson $\mathrm{H}$, Crim C, Edwards LD, et al. Inflammatory biomarkers improve clinical prediction of mortality in chronic obstructive pulmonary disease. Am J Respir Crit Care Med. 2012;185(10):1065-72

6. Garcia-Rio F, Miravitlles M, Soriano JB, Munoz L, Duran-Tauleria E, Sanchez G, Sobradillo V, Ancochea J, Committee E-SS. Systemic inflammation in chronic obstructive pulmonary disease: a populationbased study. Respir Res. 2010;11:63.

7. Knabe L, Fort A, Chanez P, Bourdin A. Club cells and CC16: another "smoking gun"? (with potential bullets against COPD). Eur Respir J. 2015; 45(6):1519-20.

8. Guerra S, Halonen M, Vasquez MM, Spangenberg A, Stern DA, Morgan WJ, Wright AL, Lavi I, Tares L, Carsin AE, et al. Relation between circulating CC16 concentrations, lung function, and development of chronic obstructive pulmonary disease across the lifespan: a prospective study. Lancet Respir Med. 2015:3(8):613-20.

9. Bernard A, Marchandise FX, Depelchin S, Lauwerys R, Sibille Y. Clara cell protein in serum and bronchoalveolar lavage. Eur Respir J. 1992; 5(10):1231-8.

10. Broeckaert F, Clippe A, Knoops B, Hermans C, Bernard A. Clara cell secretory protein (CC16): features as a peripheral lung biomarker. Ann N Y Acad Sci. 2000;923:68-77.

11. Laucho-Contreras ME, Polverino F, Gupta K, Taylor KL, Kelly E, Pinto-Plata V, Divo M, Ashfaq N, Petersen H, Stripp B, et al. Protective role for club cell secretory protein-16 (CC16) in the development of COPD. Eur Respir J. 2015 45(6):1544-56.

12. Zhu L, Di PY, Wu R, Pinkerton KE, Chen Y. Repression of CC16 by cigarette smoke (CS) exposure. PLoS One. 2015:10(1):e0116159.

13. Vestbo J, Edwards LD, Scanlon PD, Yates JC, Agusti A, Bakke P, Calverley PM, Celli B, Coxson HO, Crim C, et al. Changes in forced expiratory volume in 1 second over time in COPD. N Engl J Med. 2011;365(13):1184-92.

14. Park HY, Churg A, Wright JL, Li Y, Tam S, Man SF, Tashkin D, Wise RA, Connett JE, Sin DD. Club cell protein 16 and disease progression in chronic obstructive pulmonary disease. Am J Respir Crit Care Med. 2013:188(12):1413-9.

15. Lomas DA, Silverman EK, Edwards LD, Miller BE, Coxson HO, Tal-Singer R, Evaluation of CLtIPSEi: Evaluation of serum CC-16 as a biomarker for COPD in the ECLIPSE cohort. Thorax 2008, 63(12):1058-1063.

16. Petersen $H$, Leng $S$, Belinsky SA, Miller BE, Tal-Singer R, Owen CA, Celli B, Tesfaigzi Y. Low plasma CC16 levels in smokers are associated with a higher risk for chronic bronchitis. Eur Respir J. 2015;46(5):1501-3.

17. Laucho-Contreras ME, Polverino F, Tesfaigzi Y, Pilon A, Celli BR, Owen CA. Club cell protein 16 (CC16) augmentation: a potential disease-modifying approach for chronic obstructive pulmonary disease (COPD). Expert Opin Ther Targets. 2016;20(7):869-83.

18. Ip MS, Ko FW, Lau AC, Yu WC, Tang KS, Choo K, Chan-Yeung MM. Hong Kong thoracic S, American College of Chest P: updated spirometric reference values for adult Chinese in Hong Kong and implications on clinical utilization. Chest. 2006;129(2):384-92.

19. Lau AC, Ip MS, Lai CK, Choo KL, Tang KS, Yam LY, Chan-Yeung M. Variability of the prevalence of undiagnosed airflow obstruction in smokers using different diagnostic criteria. Chest. 2008;133(1):42-8.

20. Miller MR, Hankinson J, Brusasco V, Burgos F, Casaburi R, Coates A, Crapo R, Enright $P$, van der Grinten CP, Gustafsson $P$, et al. Standardisation of spirometry. Eur Respir J. 2005;26(2):319-38.

21. Ramirez RD, Sheridan S, Girard L, Sato M, Kim Y, Pollack J, Peyton M, Zou Y, Kurie JM, Dimaio JM, et al. Immortalization of human bronchial epithelial cells in the absence of viral oncoproteins. Cancer Res. 2004;64(24):9027-34.

22. Lam DC, Luo SY, Fu KH, Lui MM, Chan KH, Wistuba GB II, Tsao SW, Ip MS, Minna JD. Nicotinic acetylcholine receptor expression in human airway correlates with lung function. Am J Physiol Lung Cell Mol Physiol. 2016; 310(3):L232-9.

23. Lau WK, Chan SC, Law AC, Ip MS, Mak JC. The role of MAPK and Nrf2 pathways in ketanserin-elicited attenuation of cigarette smoke-induced IL-8 production in human bronchial epithelial cells. Toxicol Sci. 2012;125(2):569-77.

24. Dye BR, Hill DR, Ferguson MA, Tsai YH, Nagy MS, Dyal R, Wells JM, Mayhew CN, Nattiv R, Klein OD, et al. In vitro generation of human pluripotent stem cell derived lung organoids. elife. 2015:4.

25. Glushakova O, Kosugi T, Roncal C, Mu W, Heinig M, Cirillo P, Sanchez-Lozada LG, Johnson RJ, Nakagawa T. Fructose induces the inflammatory molecule ICAM-1 in endothelial cells. J Am Soc Nephrol. 2008;19(9):1712-20.

26. Yao XL, Ikezono T, Cowan M, Logun C, Angus CW, Shelhamer JH. Interferongamma stimulates human Clara cell secretory protein production by human airway epithelial cells. Am J Phys. 1998;274(5 Pt 1):L864-9.

27. Cowan MJ, Huang X, Yao XL, Shelhamer JH. Tumor necrosis factor alpha stimulation of human Clara cell secretory protein production by human airway epithelial cells. Ann N Y Acad Sci. 2000;923:193-201.

28. Yoon JM, Lee KH, Lee SM, Lim JJ, Yang SC, Yoo CG, Lee CT, Han SK, Shim YS, Kim YW. The immune modulation of Clara cell-10 in human peripheral monocytes and dendritic cells. Int J Mol Med. 2010;26(3):415-23. 